\title{
Cephaleuros virescens in Brazilian Mahogany: Algae Parasitic Disease Threatening an Important Reforestation Tree
}

\author{
Fabiola T. Pereira \\ Goiás State University, Ipameri Campus, Ipameri, Goiás, Brazil \\ E-mail: fabiolateodoro.p@gmail.com \\ Wanderson S. Santos \\ Goiás State University, Ipameri Campus, Ipameri, Goiás, Brazil \\ E-mail: wanderson_18wss@hotmail.com
}

Gesiane R. Guimarães

Goiás State University, Ipameri Campus, Ipameri, Goiás, Brazil

E-mail: gesianerib.guimaraes@gmail.com

Elizabeth A. A. Duarte

Maria Milza FAMAM College, Cruz das Almas, Bahia, Brazil

E-mail: elizabethaad@gmail.com

Thiago A. S. Oliveira

Maria Milza FAMAM College, Cruz das Almas, Bahia, Brazil

E-mail: oliveira.tas@gmail.com

Fabricio Rodrigues

Goiás State University, Ipameri Campus, Ipameri, Goiás, Brazil

E-mail: fabricio.rodrigues@ueg.br 
Daniel D. C. Carvalho (Corresponding Author)

Goiás State University, Ipameri Campus, Ipameri, Goiás, Brazil

E-mail: daniel.carvalho@ueg.br Tel: 55-64-3491-1556

Received: Dec. 23, 2019

Accepted: Mar. 10, 2020

Published: Mar. 19, 2020

doi:10.5296/jas.v8i1.16093

URL: https://doi.org/10.5296/jas.v8i1.16093

\begin{abstract}
The forest species are frequent targets of diseases. In this context, the plant-parasitic algae comprise a separate group in this process, including the algae genus Cephaleuros, which attacks mahogany cultivars. The objective of this work was to accomplish the molecular and morphological characterization of the causal agent of algae spots occurring in Brazilian mahogany (Swietenia macrophylla). Somatic and reproductive algae structures contained in lesions on the leaves had the DNA extracted and amplified by primers 18SHf and 18SLr of the rRNA nuclear gene $18 \mathrm{~S}$. Then, the amplicons were purified and sequenced. The algae structures too were characterized under light microscope. In addition, a total of 12 injured leaves located in the lower third of each attacked tree were randomly extracted for lesion characterization according to its size and number. After algae structures measurements, sporangiophores and sporangia had $260.2 \times 12.9 \mu \mathrm{m}$ and $25 \times 18.8 \mu \mathrm{m}$. These measurements, combined with the molecular identification, indicated that the algae found in Brazilian mahogany leaves is $C$. virescens. Attacked leaves showed an average of 33 lesions, $60 \%$ of which were smaller than $2 \mathrm{~mm}$ in diameter, which shows great capacity of the pathogen to reach different parts of the foliar limb. These measurements, combined with molecular identification, confirmed the algae found in Brazilian mahogany leaves to be $C$. virescens.
\end{abstract}

Keywords: Swietenia macrophylla King, algae, DNA

\title{
1. Introduction
}

The Brazilian mahogany (Swietenia macrophylla G. King) tree can be cultivated in tropical climate in most of Brazil, except in the South, where there are frosts. The culture of this species is considered low risk, providing that all stages of planning and execution are executed and complied with. Its wood is highly valued in the international market, as it is used to make luxury furniture, besides being an ornamental tree used in afforestation and reforestation (Carvalho, 2007; Silva et al., 2013). The forest species are a frequent target of diseases caused mainly by fungi and bacteria (Kharwar et al., 2010; Verzignassi et al., 2009), whereas the plant-parasitic algae comprise a separate group in this process, lacking research and further information.

Among such organisms, the algae of the Cephaleuros genus has higher reputation with the scientific community, particularly because it is widely distributed throughout tropical and 
subtropical regions worldwide (Gokhale \& Shaikh, 2012). According to Malagi et al. (2011), in Brazil, incidence of algae spots has already been reported in avocado, black pepper, acerola (Malpighia emarginata), annatto, cashew, black tea, yerba mate, mango (Vasconcelos et al., 2019), coffee, soursop, apple, cassava, basil, guava, olive and citrus cultivars. However, molecular studies with this genus are incipient, making the morphological and symptomatic characterization crucial for the species identification. In this respect, circular spots can be observed distributed on the adaxial surface of the leaf limb, containing protruding colonies of orangish or rusty chlorophyll pigments (Duarte et al., 2005). Over time, the spots can expand, showing smooth surface in grayish-brown color and taking a large leaf area (Han et al., 2011).

The damage caused by Cephaleuros comes from the reduction in the leaf photosynthetic area, which may represent economic loss, especially in times of high humidity and temperature (Malagi et al., 2011; Piccinin et al., 2005). In this context, knowledge of plant diseases is important when considering the adoption of measures for integrated management and productivity increase. Therefore, correct identification of the pathogen is necessary, constituting the first step towards subsequent disease control. Regarding the Cephaleuros morphological characterization, there is no standardization as to which characters should be measured and, although measures of the most known characters have already been published, some need to be reevaluated (Rindi \& López-Bautista, 2008). Additionally, some isolates of Cephaleuros have been identified through the sequencing of conserved genes, occurring in mango trees (Vasconcelos et al., 2018). As a result, this study was designed to carry out the morphological characterization and molecular identification of the causal agent of algae spots in Brazilian mahogany.

\section{Methods}

\subsection{Morphological Characterization}

Brazilian mahogany leaves (10-year-old trees) presenting symptoms of algal spot disease were collected in November 2012 in the Campus of the Goias State University (UEG),

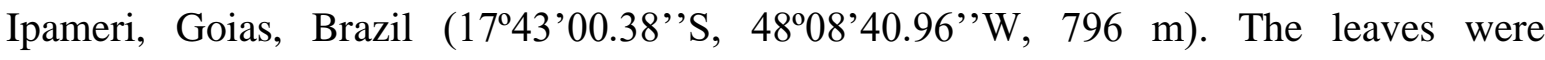
exhibiting lesions grew larger and protruding. Then, microscope slides were made using SDW as a mounting means and removing body structures with a platinum needle and lesion scraping. Images of the morphological structures were rendered in a Leica DM500 light microscope with an ICC 50 HD digital camera attached. The algae structure measurements were performed using the LAS EZ 2.0 (100x) software, with an average of 30 measurements for each structure (length, width, coloring and shape of the sporangiophore and sporangium). In addition, a total of 12 injured leaves located in the lower third of the injured tree were randomly extracted for determination of lesion size, into three classes: (Class 1: lesions up to 0.1 to $2.0 \mathrm{~mm}$ in diameter; Class 2: 2.1 to $4.9 \mathrm{~mm}$ and Class 3: lesions larger than $5.0 \mathrm{~mm}$ in diameter) and number of lesions per leaf. A total of five trees were sampled. 


\subsection{Molecular Characterization}

Leaves from the same batch of the previous item were recovered aiming to the molecular characterization. The material was sent to the Laboratory of Genetics and Molecular Biology of the Federal University of the Reconcavo of Bahia (UFRB), where molecular analysis was carried out. The leaf damaged areas were excised and the algae vegetative and reproductive tissue obtained was used for DNA extraction using UltraClean ${ }^{\circledR}$ Microbial DNA Isolation kit (Mobio, USA), following the manufacturer's recommendations. The DNA integrity and quantity were verified by using agarose gel electrophoresis at $0.8 \%$ and Qubit $^{\circledR}$ 2.0 Fluorometer (Invitrogen), respectively. PCR amplifications were performed with universal primers of the rRNA 18S nuclear gene (Hamby et al., 1988), designated as 18SHf and 18SLr, using the following reagents and concentrations: $60 \mathrm{ng}$ DNA from each sample; 1x Taq DNA polymerase enzyme buffer; $3.7 \mathrm{mM} \mathrm{MgCl}_{2}$; 0.6 pmol dNTPs; 0.4 pmol of each primer; $5 \mathrm{U}$ Taq DNA polymerase, adjusted to a final volume of $50 \mu \mathrm{l}$ with ultrapure water. The amplification cycles were performed in a Veriti Thermal Cycler PCR (Applied Biosystems) at initial denaturation temperature of $95{ }^{\circ} \mathrm{C}$ for 3 minutes; 30 amplification cycles at $95{ }^{\circ} \mathrm{C}$ for 1 minute; $52{ }^{\circ} \mathrm{C}$ for 1 minute; $72{ }^{\circ} \mathrm{C}$ for 2 minutes, and final extension at $72^{\circ} \mathrm{C}$ for 10 minutes. The amplified products were visualized in agarose gel at $1 \%\left(\mathrm{wt} \mathrm{vol}^{-1}\right)$, stained with $\mathrm{EtBr}$ and visualized under UV light. Then, the amplicons were purified using the PureLink ${ }^{\mathrm{TM}}$ PCR Purification kit (Invitrogen) for subsequent nucleotide identification using the automatic sequencer ABI-PRISM 310 Genetic Analyzer (Applied Biosystems). The editing and assembling of sequences were performed with the Sequencher 4.1.4 software (Gene Code Corporation). The taxonomic identity of the isolates was verified through the GenBank database, using the Basic Local Alignment Search Tool (BLAST) of NCBI (http://www.ncbi.nlm.nih.gov).The sequence for the Cephaleuros virecens form Brazilian mahogany leaves was deposited in GenBank database with accession number KR535994. Data on the algae structure measures were subjected to variance analysis and the number of leaf injuries data were submitted to Scott-Knott test $(\mathrm{P} \leq 0.05)$ using the SISVAR 5.3 software (Ferreira, 2011).

\section{Results and Discussion}

The mahogany leaves showed round, velvety, greenish-yellow lesions on the limb spread throughout the adaxial surface (Figures $1 \mathrm{a}$ and $1 \mathrm{~b}$ ). The lesion average diameters obtained were $1.3 ; 2.9$ and $5.5 \mathrm{~mm}$ with variation coefficients $15.17 ; 10.66$ and $16.53 \%$ for Classes 1 , 2 and 3, respectively (Table 1). As for the number of leaf lesions, they were found to be statistically different: 19.4, 11.4 and2.6 lesions per leaf for Classes 1, 2 and 3, respectively. 


\section{I Macrothink}
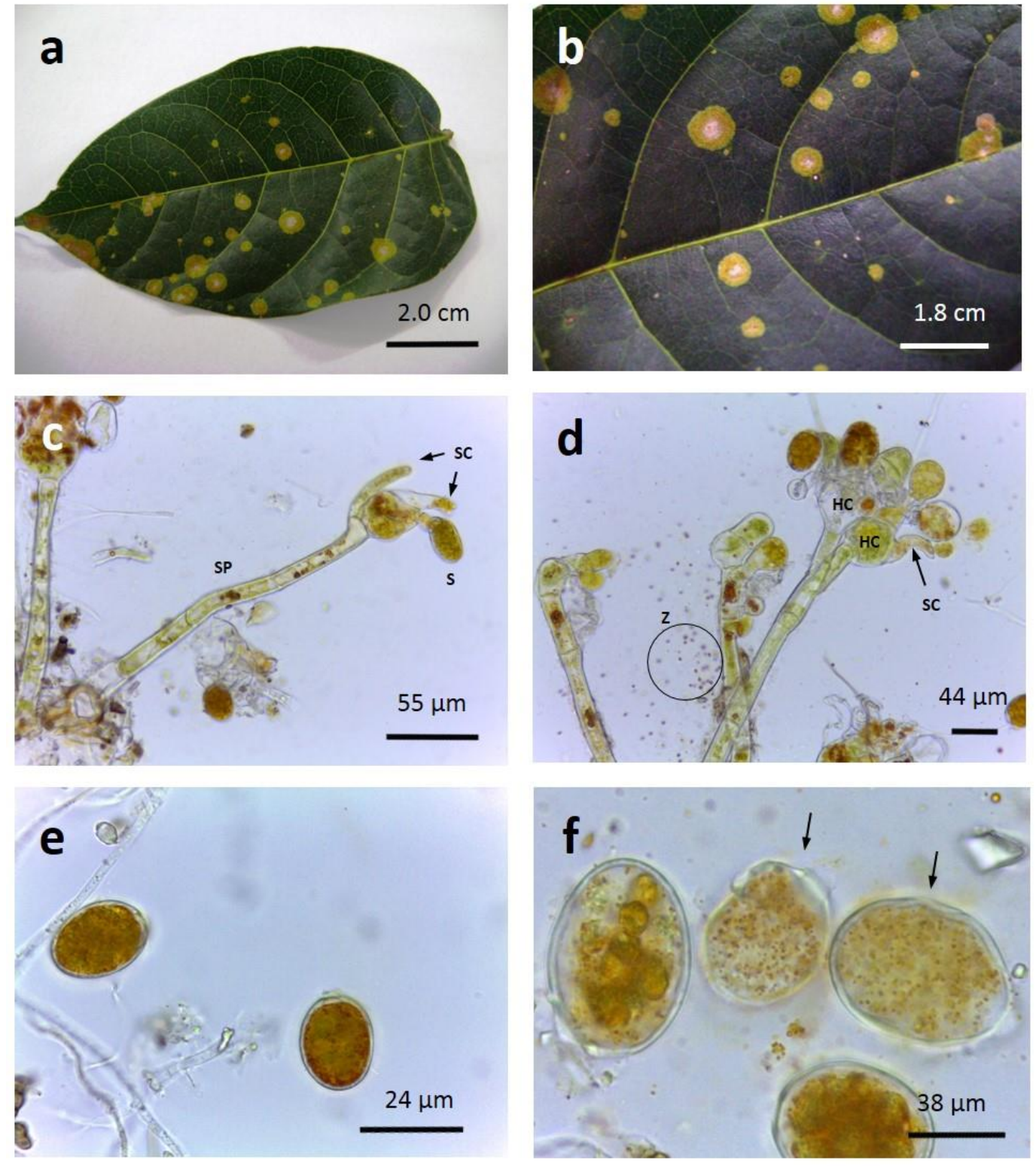

Figure 1. (a) Brazilian mahogany leaf showing symptoms of algal spots; (b) Close-up of symptoms on mahogany leaf; (c) SP - sporangiophore, SC - suspensor cell, Ssporangium; (d)Z - zoospores, HC - head cell, SC - suspensor cell(e)sporangia; (f)

Close-up of sporangia in containing mature zoospores 


\section{Macrothink}

Journal of Agricultural Studies

ISSN 2166-0379

2020, Vol. 8, No. 1

Table 1. Average diameter $(\varnothing \mathrm{mm})$ and number of lesions of algae spot per leaf of Brazilian mahogany. Ipameri, Goias, Brazil

\begin{tabular}{cccc}
\hline \multirow{2}{*}{ Classes } & $\varnothing(\mathrm{mm})$ & $\begin{array}{c}\text { Lesion average diameter } \\
\text { variation }(\%)\end{array}$ & $\begin{array}{c}\text { Number of lesions } \\
\text { per leaf }^{(1)}\end{array}$ \\
\cline { 2 - 4 } & 1.3 & 15.17 & $19.4 \mathrm{a}$ \\
2 & 2.9 & 10.66 & $11.4 \mathrm{~b}$ \\
3 & 5.5 & 16.53 & $2.6 \mathrm{c}$ \\
\hline $\begin{array}{c}\text { Coefficient of variation } \\
(\%)\end{array}$ & - & - & 44.0 \\
\hline
\end{tabular}

${ }^{(1)}$ Values followed by the same letter in each column do not differ significantly by Scott-Knott test $(\mathrm{P} \leq 0.05)$

After algae structure measurement, the sporangiophores were found to have from 150.0 $407.3 \times 8.0-18.8 \mu \mathrm{m}(260.2 \times 12.9 \mu \mathrm{m})$ (Figure 1c), whereas the sporangia measured $18.2-$ $31.6 \times 16.5-21.3 \mu \mathrm{m}(25.1 \times 18.8 \mu \mathrm{m})$ (Figures 1e and 1f). The number of sporangiophore septa ranged from 2 to 5 (Figure 1c) with an average of 3.1 septa per sporangiophore. The total number of sporangia produced by each sporangiophore was 2 to 5 (Figures 1c and 1d), reaching an average of 3.2, 1.4 of which attached to the sporangiophore suspensor cell and 1.8 detached from it. Table 2 summarizes the morphological characteristics obtained from the algae occurring in Brazilian mahogany compared to similar reports on other economically important crops.

Table 2. Characteristics of Cephaleuros in different hosts, including $C$. virescens found on Brazilian mahogany, Ipameri, Goias, Brazil

\begin{tabular}{|c|c|c|c|c|c|}
\hline \multirow{2}{*}{ Algal species } & \multirow{2}{*}{ Host } & \multicolumn{2}{|c|}{ Sporangiophore $(\mu \mathrm{m})$} & \multicolumn{2}{|c|}{ Sporangium $(\mu \mathrm{m})$} \\
\hline & & Length & Width & Length & Width \\
\hline $\begin{array}{l}\text { Cephaleuros } \\
\text { virescens }^{(1)}\end{array}$ & $\begin{array}{l}\text { Swietenia } \\
\text { macrophylla }\end{array}$ & $\begin{array}{c}150.0- \\
407.3\end{array}$ & $8.0-18.8$ & $18.2-31.6$ & $16.5-21.3$ \\
\hline $\begin{array}{l}\text { Cephaleuros } \\
\text { virescens }^{(2)}\end{array}$ & Ficus benghalensis & $500-1000$ & $12.0-25.0$ & 30.0 & 22.0 \\
\hline $\begin{array}{l}\text { Cephaleuros } \\
\text { virescens }^{(3)}\end{array}$ & $\begin{array}{c}\text { Citrus sinensis, } C \text {. } \\
\text { reticulata, } C . \\
\text { limetta }\end{array}$ & 200.4 & 15.9 & 20.0 & 19.6 \\
\hline $\begin{array}{l}\text { Cephaleuros } \\
\text { parasiticus }^{(4)}\end{array}$ & Camellia sinensis & $880-1256$ & $22.5-32.2$ & $17.4-27.5$ & $17.4-20.8$ \\
\hline
\end{tabular}

${ }^{(1)}$ C. virescens found in Brazilian mahogany leaves; ${ }^{(2)}$ Malagi et al. (2011); ${ }^{(3)} \mathrm{Han}$ et al. (2011); 
${ }^{(4)}$ Ponmurugan et al. (2010). 2020, Vol. 8, No. 1

A sequence of 538 base pairs was obtained from primers 18SHf and 18SLr of the rRNA 18S nuclear gene. The fragment aligned with 13 Cephaleuros sequences, 10 of which being $C$. virescens sequences and 3 being $C$. parasiticus sequences deposited with GenBank. However, the greatest similarity coefficients were found for $C$. virescens (Table 3). Symptomatic leaves, used for the molecular and morphological analysis were deposited and stored in the UEG's Herbarium of Plant Diseases under the registration number H-29-01.

Table 3. Molecular identification based on similarity coefficients found in the DNA of $C$. virescens deposited at GenBank

\begin{tabular}{|c|c|c|c|}
\hline $\begin{array}{c}\text { Access } \mathrm{n}^{\circ} \text { in } \\
\text { Herbarium and NCBI }\end{array}$ & Query size (bp) ${ }^{(1)}$ & Identity $^{(2)}$ & $\begin{array}{l}\text { Access } n^{\circ} \\
\text { references } \\
(3)\end{array}$ \\
\hline \multirow{5}{*}{$\begin{array}{c}\text { H-29-01 } \\
\text { KR535994 }\end{array}$} & \multirow{5}{*}{538} & $95 \%$ & AY052564 \\
\hline & & $94 \%$ & $\mathrm{KM} 020142^{(5)}$ \\
\hline & & $93 \%$ & AY220984 $(6)$ \\
\hline & & $93 \%$ & DQ399585(6) \\
\hline & & $93 \%$ & DQ399584 ${ }^{(6)}$ \\
\hline
\end{tabular}

${ }^{(1)}$ Amplicons were sequenced in both orientations and the consultation fragments presented correspond to the obtained sequence; ${ }^{(2)} \mathrm{E}$-values were equal to zero for isolates $(100 \%$ coverage $) ;{ }^{(3)}$ Access numbers references corresponding to the descriptive sequences indicated in the previous column; ${ }^{(4)}$ López-Bautista \& Chapman $(2003)$; ${ }^{(5)}$ Friedl et al. (2019); ${ }^{(6)}$ López-Bautista et al. (2006).

Besides the morphological differences, $C$. virescens and $C$. parasiticus differ as to host symptoms. According to Nelson (2008), C. virescens algae species appear on the leaf adaxial surface, with orange to brown or rusty color lesions with circular areas of up to 2 $\mathrm{cm}$ diameter, being a subcuticular parasite wherein $C$. virescens is considered to be relatively harmless to plants. As for the $C$. parasiticus algae species, it causes full thickness necrosis to the plant leaf abaxial surface and to all intervening tissues. Moreover, $C$. parasiticus is an intercellular parasite, where more tissue damage occurs than in subcuticular ones caused by $C$. virescens.

Based on the morphological characteristics presented in Table 2, the measurements obtained for Cepahleuros structures in Brazilian mahogany plants were found to be close to those obtained for $C$. virescens in citrus trees in Brazil (Malagi et al., 2011). Another important feature of $C$. virescens species is the sporangiophore length, which, when occurring in Brazilian mahogany, was $150.0-407.3 \mu \mathrm{m}$ (Table 2). Conversely, the C. parasiticus algae 
have larger sporangiophore length and width: $880-1256 \mu \mathrm{m} \times 22.5-32.2 \mu \mathrm{m}$ (Ponmurugan et al., 2010). Therefore, there is great difference mainly as to width, since for C. virescens in Brazilian citrus and mahogany the average was 15.9 and $12.9 \mu \mathrm{m}$, respectively. As a result, the characteristics presented in Table 2, together with the molecular characterization, indicated that the algae found in Brazilian mahogany ( $S$. macrophylla) was $C$. virescens. A hindrance point for the distinction between $C$. parasiticus and $C$. virescens based on morphological characters would be the small overlapping areas in sporangiophore dimensions obtained by some authors. However, these overlapping areas are very limited and do not compromise the morphological taxonomy. As an example, the minimum sporangiophore dimensions obtained by Han et al. (2011) can be mentioned, which are do not happen in $C$. parasiticus. Furthermore, the starting point for sporangiophores $C$. parasiticus dimensions corresponds to the maximum found for $C$. virescens (Ponmurugan et al., 2010).

Malagi et al. (2011) claimed that there is higher algae spot incidence on the shaded leaves of the plant lower third, and this motivated the collection of leaves in the lower third of Brazilian mahogany trees to obtain the data shown in Table 2. Interestingly, attacked leaves showed on average 33 lesions, which can be considered a low value when compared with Mycosphaerella citri, which showed on average 131 injuries per leaf (Silva et al., 2009). Moreover, $60 \%$ of the algae spot lesions were smaller than $2 \mathrm{~mm}$ in diameter (Class 1), which demonstrates greater capacity of the pathogen to reach different points of the leaf limb. Within the same injury class, there is little variation among sizes, suggesting symmetry typical of algae spots. According to Keller et al. (2000), the number of lesions is an important fact because it is a variable highly correlated with the disease severity.

The occurrence of algae spots is favored by average monthly temperatures around $23^{\circ} \mathrm{C}$ and average monthly rainfall of $127 \mathrm{~mm}$ (Malagi et al., 2011). During the month of November 2012, when collection of damaged leaves was carried out to obtain the data in Table 2, the temperature in Ipameri town ranged from 18.3 to $38.0^{\circ} \mathrm{C}$, a condition associated with precipitation of $133.9 \mathrm{~mm}$ (Inmet, 2015) that favors the disease development. This occurs because rainy periods with temperature ranging from 28 to $32^{\circ} \mathrm{C}$ are ideal for the envelope membrane of sporangia to break, which facilitates wind dispersion of zoospores (Duarte et al., 2005).

Another object of this research was the variability of measurements obtained from $C$. virescens sporangiophores and sporangia, where variation coefficients of 31.28 and $22.06 \%$ for sporangiophore length and width and 11.94 and $6.68 \%$ for sporangia length and width, respectively, were observed. There are no reports on the measurement variability found in $C$. virescens. However, it can be inferred that the variability found for the sporangia is close to those found in studies in the mycology area (Carvalho et al., 2008). These values are important because they show that the sporangiophores length is more variable when compared with other structures measured. Finally, it is worth noting that the homogeneity obtained in the measurement of micromorphological structures helps the characterization and standardization of $C$. virescens structure measurement. 
Hamby et al. (1988) report that the information from the rRNA 18SHf and 18SLr gene is important for the differentiation of Cephaleuros pathogenic species. Similarly, this study enabled the identification of the $C$. virescens algae from the excision of symptomatic leaf lesions, despite the reduced number of sequences of this kind deposited at GenBank. On this platform, sequences of Trentepohlia and Phycopeltis species included in the same Cepahleuros monophyletic group occur in greater amount (Boedeker et al., 2013; López-Bautista et al., 2006; Rindi et al., 2009; Suutari et al., 2010).

The phylogenetic proximity between $C$. virescens and $C$. parasiticus was present in previous studies (López-Bautista \& Chapman, 2003; López-Bautista et al., 2006; Zhu et al., 2015). Therefore, the alignment of H-29-01 sequence with $93 \%$ similarity to $C$. parasiticus not invalidate the morphological results that refer to $C$. virescens. Similarity equal to and greater than 93\% was assigned to $C$. virescens sequences deposited in GenBank (Table 3). Although both C. virescens and C. parasiticus typically occur in leaves, the lack of genetic information caused by very short length or contamination by other microorganisms Trentepohliaceae can explain this phenomenon.

\section{Conclusion}

The conclusions of this research are: symptomatology-based descriptions associated to morphologic and molecular characterization indicated that $C$. virescensis the algae found on leaves of Brazilian mahogany ( $S$. macrophylla) in the state of Goias, Brazilian attacked leaves showed on average 33 lesions, $60 \%$ of which were smaller than $2 \mathrm{~mm}$ in diameter, evidencing greater capacity of the pathogen to injure different parts of the foliar limb.

\section{Acknowledgements}

The authors thank the National Council for Scientific and Technological Development (CNPq) for the scientific initiation scholarship, the Foundation for Support to Goias State Research (FAPEG) for the master's program scholarship and financial assistance in the paper preparation, the Coordination for the Improvement of Higher Education (CAPES) for two Post-doctorate scholarships, and the Scholarship Program for Incentive to Scientific Research and Production (PROBIP) of Goias State University (UEG) for the scholarship in research production.

\section{References}

Boedeker, C., Karsten, U., Leliaert, F., \& Zuccarello, G. C. (2013). Molecular, biochemical and morphological data suggest an affiliation of Spongiochrysis hawaiiensis with the Trentepohliales (Ulvophyceae, Chlorophyta). Phycological Research, 61, 133-14. https://doi.org/10.1111/pre.12011

Carvalho, D. D. C., Alves, E., Batista, T. R. S., Camargos, R. B., \& Lopes, E. A. G. L. (2008). Comparison of methodologies for conidia production by Alternaria alternate from citrus. $\begin{array}{llll}\text { Brazilian Journal of } & \text { Microbiology, } & \text { 39(4), }\end{array}$ https://doi.org/10.1590/S1517-83822008000400036

Carvalho, P. E. R. (2007). Mogno Swietenia macrophylla. Embrapa Florestas, Colombo, 
Brasil, 2007, 12p. (Circular Técnica, 140).

Duarte, M. L. R., Albuquerque, F. C., \& Albuquerque. P. S. B. (2005). Doenças da pimenta-do-reino. In: Manual de Fitopatologia: Doenças das plantas cultivadas. 4.ed. v.2. Ed by Kimati, H.; Amorim, L.; Rezende, J. A. M.; Bergamim Filho, A.; Camargo, L. E. A. Agronômica Ceres, São Paulo, Brasil. 2005. pp.507-516.

Ferreira, D. F. (2011). Sisvar: a computer statistical analysis system. Ciência e Agrotecnologia, 35(6), 1039-1042. http://dx.doi.org/10.1590/S1413-70542011000600001

Friedl, T., Hepperle, D., Marrero-Callico, A., Jahn, R.; Kusber, W. H., \& Hallmann, C. (2019). Unpublished. Cephaleuros virescens strain SAG $1.8618 S$ ribosomal RNA gene, partial sequence. GenBank: KM020142.1. https://www.ncbi.nlm.nih.gov/nuccore/KM020142.1 Accessed May 2, 2019

Gokhale, M. V., \& Shaikh, S. S. (2012). Host range of a parasitic alga Cephaleuros virescens kunz. Ex fri. from Maharashtra State, India. Plant Sciences Feed, 2, 1-4.

Hamby, R. K., Sims, L., Issel, L., \& Zimmer, E. (1988). Direct ribosomal RNA sequencing: optimization of extraction and sequencing methods for work with higher plants. Plant Molecular Biology Reporter, 6(3), 175-192. https://doi.org/10.1007/BF02669591

Han, K., Park, M., Park, J., \& Shin. H. (2011). First report of algal leaf spot associated with Cephaleuros virescens on greenhouse grown Ficus benghalensis in Korea. Australasian Plant Disease Notes, 6, 72-73. http://dx.doi.org/10.1007/s13314-011-0024-8

INMET. (2015). Instituto Nacional de Meteorologia, Ministério da Agricultura, Pecuária e Abastecimento. http://www.inmet.gov.br/portal/index.php?r=bdmep/bdmep Accessed April 1, 2015.

Keller, B., Feuillet, C., \& Messmer, M. (2000). Genetics of disease resistance: Basic concepts and application in resistance breeding. In: Mechanisms of Resistance to Plant Diseases. eds. by Slusarenko, A. J.; Fraser, R.S.S.; Van Loon, L.C. Kluwer Academic Publishers, Dordrecht, Netherland. 2000, 101-160. https://doi.org/10.1007/978-94-011-3937-3_5

Kharwar, R. N., Gond, S. K., Kumar A., \& Mishra, A. (2010). A comparative study of endophytic and epiphytic fungal association with leaf of Eucalyptus citriodora Hook., and their antimicrobial activity. World Journal of Microbiology and Biotechnology, 26, 1941-1948. https://doi.org/10.1007/s11274-010-0374-y

López-Bautista, J. M., \& Chapman, R. L. (2003). Phylogenetic affinities of the Trentepohliales inferred from small-subunit rDNA. International Journal of Systematic and Evolutionary Microbiology, 53(6), 2099-2106. https://doi.org/10.1099/ijs.0.02256-0

López-Bautista, J. M., Rindi, F., \& Guiry. M. D. (2006). Molecular systematics of the subaerial green algal order Trentepohliales: an assessment based on morphological and molecular data. International Journal of Systematic and Evolutionary Microbiology, 56(7), 1709-1715. https://doi.org/10.1099/ijs.0.63990-0 
Malagi, G., Santos, I., Mazaro, S. M., \& Guginski, C. A. (2011). Detecção de mancha-de-alga (Cephaleuros virescens Kunze) em citros no estado do Paraná. Revista Brasileira de Agrociência, 17(1), 148-152. https://dx.doi.org/10.18539/cast.v17i1.2042

Nelson, S. C. (2008). Cephaleurus species, the plant-parasitic green algae. Plant Disease, 43, $1-6$.

Piccinin, E., Pascholati, S. F., \& Di Piero, R. M. (2005). Doenças do abacateiro. H.; Amorim, L., Rezende, J. A. M., Bergamim Filho, A., Camargo, L. E. A. (2005). Manual de Fitopatologia: Doenças das plantas cultivadas.4.ed. v.2. Ed by Kimati, Agronômica Ceres, São Paulo, Brasil, 01-07.

Ponmurugan, P., Saravanan, D., \& Ramya, M. (2010). Culture and Biochemical Analysis of a tea algal pathogen, Cephaleuros parasiticus. Journal of Phycology, 46, 1017-1023. https://doi.org/10.1111/j.1529-8817.2010.00879.x

Rindi, F., \& López-Bautista, J. M. (2008). Diversity and ecology of Trentepholiales (Ulvophyceae, Chlorophyta) in French Guiana. Cryptogamie Algologie, 29(1), 13-43.

Rindi, F., Lam, D. W., \& López-Bautista, J. M. (2009). Phylogenetic relationship and species circumcription in Trentepohlia and Printzina (Trentepohliales, Chlorophyta). Molecular and Phylogenetics Evolution, 52(2), 329-339. https://doi.org/10.1016/j.ympev.2009.01.009

Silva, M. C. A., Rosa, L. S., \& Vieira, T. A. (2013). Eficiência do nim (Azadirachta indica A. Juss) como barreira natural ao ataque de Hypsipyla grandella (Zeller (Lepidoptera: Pyralidae) sobre o mogno (Swietenia macrophylla King). Acta Amazonica, 43(1), 19-24. https://doi.org/10.1590/S0103-84782008005000098

Silva, S. X. B., Laranjeira, F. F., Soares, A. C. F., \& Michereff, S. J. (2009). Amostragem, caracterização de sintomas e escala diagramática da mancha graxa dos citros (Mycosphaerella citri) no Recôncavo Baiano. Ciência Rural, 39(3), 896-899. http://dx.doi.org/10.1590/S0103-84782008005000098

Suutari, M., Majaneva, M., Fewer, D. P., Voirin, B., Aiello, A., Friedl, T., Chiarello, A. G., \& Blomster, J. (2010). Molecular evidence for a diverse green algal community growing in the hair of sloths and a specific association with Trichophilus welckeri (Chlorophyta, $\begin{array}{llll}\text { Ulvophyceae). } \quad B M C & \text { Evolutionary } & \text { Biology, } & \text { 10(86), }\end{array}$ https://doi.org/10.1186/1471-2148-10-86

Vasconcelos, C. V., Muniz, P. H. P. C., Duarte, E. A. A., Oliveira, T. A. S., Santos, W. S., Barboza, M. E. S., ... Carvalho, D. D. C. (2019). Morphological Characterization of Cephaleuros virescens occurring in Mango Trees. Journal of Agricultural Science, 11(11), 156-161. https://doi.org/10.5539/jas.v11n11p156

Vasconcelos, C. V., Pereira, F. T., Duarte, E. A. A., Oliveira, T. A. S., Peixoto, N., \& Carvalho, D. D. C. (2018). Physiological and Molecular Characterization of Cephaleuros virescens occurring in Mango Trees. Plant Pathology Journal, 34(3), 1-6. https://doi.org/10.5423/PPJ.OA.09.2017.0194 
Verzignassi, J. R., Poltronieri, L. S., \& Benchimol, R. L. (2009). Mancha-alvo em mogno-africano no Brasil. Summa Phytopathologica, 35(1), 70-71. https://doi.org/10.1590/S0100-54052009000100015

Zhu, H., Zhao, Z., Xia, S., Hu, Z., \& Liu, G. (2015). Morphological examination and phylogenetic analysis of Phycopeltis spp. (Trentepohliales, Ulvophyceae) from tropical China. PLoS ONE, 10, 1-19. https://doi.org/10.1371/journal.pone.0114936

\section{Copyright Disclaimer}

Copyright for this article is retained by the author(s), with first publication rights granted to the journal.

This is an open-access article distributed under the terms and conditions of the Creative Commons Attribution license (http://creativecommons.org/licenses/by/4.0/). 